\title{
Directors' Responsibilities in a Corporate Bankruptcy
}

\author{
Meiske M. W. Lasut* \\ Law Studies Program \\ Faculty of Social Sciences, \\ Universitas Negeri Manado \\ Manado, Indonesia \\ meikselasut@unima.ac.id
}

\author{
Engeli Yuliana Lumaing \\ Law Studies Program \\ Faculty of Social Sciences, \\ Universitas Negeri Manado \\ Manado, Indonesia \\ enjelilumaing@gmail.com
}

\begin{abstract}
The Board of Directors is a limited liability company organ (PT) has an important role in managing the company and conducting activities to represent the company, both inside and outside the court. The Board of Directors is fully responsible for the management of PT. In conducting authorities, directors should able to start from the foundation which the tasks and positions obtained are based on several principles, called the fiduciary duty principle, the principal duty of skill and care, the principal duty of loyalty, and the principle of no secret profit rule doctrine of corporate opportunity. In the case of a PT bankruptcy, the directors may be asked for responsible, if the directors of the PT are unavailable or negligence. This study aimed to determine explicitly of directors' responsibilities in the bankruptcy of the company for the creditors to get their rights when a company is declared bankrupt by the Commercial Court. While the source of data comes from secondary data which are consisting of primary, secondary and tertiary legal material. Primary legal material consists of legislation relating to the UUPT and UUKPKPU as well as other relevant policies. Secondary legal material in the form of consumer protection books, papers, other scientific works related to the bankruptcy of a company.
\end{abstract}

\section{Keywords: Responsibility, Directors, Bankruptcy}

\section{INTRODUCTION}

Ltd (PT) is a legal entity and the amount of the company's capital is listed in the articles of association. Company property is separate from the personal wealth of the owner of the company, has its assets. Each person can own more than one share which is proof of company ownership. Shareholders have limited liability as many shares as they have. If the company's debt exceeds the company's wealth, then the excess debt is not the responsibility of the shareholders. If the company gets a profit is distributed according to the stipulated provisions.

The Board of Directors is Ltd organ has an important role in managing the company and is tasked to conduct activities represent the company, both inside and outside the court. The Board of Directors is fully responsible for the management of PT. In conducting its duties and authorities, directors should depart from the foundation the tasks and positions obtained are based on several basic principles, namely the fiduciary duty principle, the principle of duty of skill and care, the principle of duty of loyalty, and the principle of no secret profit rule doctrine of corporate opportunities. In the event of a PT bankruptcy, the directors may be held accountable, if the directors of the PT are in error or negligence. The Board of Directors is also referred to as the company's management as a complementary tool for the company conducted all the activities and represents the company, both inside and outside the court. Thus the scope of the board of directors' duties is to take care of the company.

In implementing the management of the Company, the directors are not only responsible for the Company and the Company's shareholders, but also for third parties who have legal relations and are related to the Company, both directly and indirectly with the Company. Therefore a board of directors should act carefully in conducting their duties.

The Board of Directors is fully responsible for the management and running of the Company for the interests and objectives of the Company. In conducting their duties, the directors are given full rights and power, with the consequence every action taken by the directors will be considered and treated as the actions and actions of the Company, as long as they act according to the Company's articles of association. As long as the directors do not violate the Company's articles of association, the Company will bear the consequences of the directors' actions. As for the actions of the directors that are detrimental to the Company, which are conducted beyond the limits and authority given by the articles of association, may not be recognized by the company. This means the directors are personally responsible for their actions beyond the authority given in the Company's articles of association.

Ltd Law Article 97 regulates that management is entrusted to the directors should be conducted in good faith and with full responsibility, which directors are proven wrong or negligent in conducting their management (having bad intentions) resulting in the Company's loss, the Company's shareholders according to the provisions there is a right to sue the relevant directors for full accountability, up to their assets. Each member of the board of directors is responsible for his negligence and mistakes that result in the Company's loss, in this case, bankruptcy.

Research Questions: (1). What is the directors' responsibility in the company's bankruptcy. (2). How to determine a director is negligent in conducting his duties to be responsible for the company's bankruptcy. 


\section{RESEARCH METHODS}

This research is legal. As Peter Mahmud Marzuki stated, legal research is a process of finding legal rules, legal principles, and legal doctrines to address the legal issues at hand. The type of research used is normative legal research or library research. Normative law research examines the conceptualized law as a valid norm. The prevailing legal norms are in the form of positive written legal norms or rules formed by statutory institutions, codifications, laws, government regulations and their standards. Normative legal research or library legal research includes (1) research on legal principles; (2) research on legal systems; (3) research on the degree of vertical and horizontal synchronization; (4) legal comparison; (5) and legal history.

\section{RESULTS AND DISCUSSION}

\section{Responsibilities of the director in bankruptcy of the} company

Ltd is a form of legal business entity, which was originally known by the name Naamloze Vennootschap (NV). The term "limited" in an Ltd refers to the responsibilities of shareholders which are limited to the nominal value of all shares owned [1]. According to article 1 letter 1 of Law No. 40 of 2007, which is meant by Ltd, as follows. "A legal entity which is a capital alliance is established based on an agreement, conducts business activities with authorized capital which is entirely divided into shares and meets the requirements stipulated in this law."

From a legal standpoint, Ltd provides safety signs and regulates the balance of the interests of all parties that are implemented as well as possible to conduct economic activities. Therefore, this limited liability company is in high demand by the public. Ltd is a perfect form of business, both in terms of economic unity and legal aspects. Ltd of the economy is regulated perfectly by law, it can function as a perfect business entity. Likewise, because this type of business entity is a legal entity, has a position as a subject capable of conducting legal actions, as a supporter of rights and obligations in legal traffic.

The company has the status of a legal entity after the company deed of establishment is approved by the minister. As a legal entity, the company has goals and interests. And to achieve these objectives the company has the equipment to conduct activities in the intent known to the directors, or those responsible for the company.

Directors or management of a company is the company's equipment to conduct the company's activities and represent the company both inside and outside the court. In other words, the board of directors has the scope of duties as a corporate administrator. The appointment of the board of directors is conducted by the GMS, but for the first time, the appointment is made by including the composition and name of the board of directors in the deed of establishment. To be able to run the company by obtaining maximum results to the directors, they are given responsibility and authority, including representing the company inside or outside the court. Reference [2], divided the directors' authority into 3 (three) things, namely:
1. The quality of the authority of the directors representing the company is unlimited and unconditional. This means that in the case of acting for the company the directors do not need to obtain power of attorney from the company because the power they have on behalf of the company is an inherently inherent authority in themselves and the position of directors based on the law.

2. Each member of the board of directors is authorized to represent the company. The provisions of the Company Law relating to this in Article 98 paragraph (2), if a member of the board of directors consists of more than 1 (one) person, then each member of the board of directors is authorized to represent the company.

3. In certain cases, the members of the board of directors are not authorized to represent the company. According to Article 99 of Company Law in terms of:

a. There was a case in the Court between the company and the member of the board of directors concerned,

b. The member of the board of directors concerned has a conflict of interest with the company.

Members of the board of directors are appointed by the GMS to take care of the company. In their duties to take care of the company, it is required to take care of the company based on the principle of good faith. This obligation is emphasized in Article 85 paragraph 1 of the Company Law, each member of the board of directors should be in good faith and full of responsibility in conducting their duties for the interests and business of the company. Based on good faith, the law intends each member of the board of directors can avoid actions that benefit personal interests at the expense of the company's interests.

Directors are required to take full responsibility for the management of the company for the interests and purposes of the company, as well as representing the company, both inside and outside the court. Directors in good faith and full responsibility should conduct duties for the interests and business of the company. The directors 'responsibility is based on 2 (two) important principles, namely the principle that was born due to the duties and positions entrusted to him by the company (fiduciary duty) and the principle which refers to the ability and caution of the directors' actions (duty of skill and care ), both of these principles require directors to act prudently and accompanied by good faith, solely for the interests and objectives of the company. Responsibility means the obligation of an individual to conduct activities assigned to him as best as possible according to the capabilities they have. The responsibilities of directors can be distinguished in:

1. Internal responsibility, which includes the duties and responsibilities of the company's directors and shareholders,

2. External responsibilities, relating to the duties and responsibilities of directors to third parties which have direct or indirect legal relations with the company [3].

Directors can be sued personally to the District Court if the company suffers losses due to errors and negligence. Likewise, in the event of bankruptcy occurs an error or negligence of the directors and the company's wealth is not enough to cover losses due to the bankruptcy, then 
each member of the board of directors is jointly and severally liable for the losses.

In the event of a bankruptcy of the company, the directors are not a priori personally responsible for the company, but on the contrary that the directors should be free of responsibility for the bankruptcy of PT. The responsibility of directors whose companies go bankrupt, in principle is the same as the responsibilities of directors whose companies do not go bankrupt.

The bankruptcy of PT either directly or indirectly will cause legal consequences for its management, especially for the directors of the company. There are many problems regarding the legal consequences arising from the decision on PT bankruptcy, one of which is the extent of accountability for the existence of PT bankruptcy, whether the legal entity itself will assume responsibility or whether the company's organs in this case directors will be personally responsible [3]. The criteria for directors' responsibility are as follows:

1. That responsibility arises if the company goes through bankruptcy procedures.

2. There should be an error or omission.

3. Responsibility is residual, meaning that responsibility arises if later it turns out the assets of the company taken are not enough.

4. That responsibility means even if only a creditor is at fault, the other directors are held responsible.

5. Assumption of guilt with inverse proof.

A further arrangement of the directors' responsibilities can be seen from certain conditions. In principle, directors are not personally responsible for acts committed on behalf of the company based on the authority they have. This is because the directors' actions seen as actions of the Ltd (PT) which is a legal subject. However, there are several things that directors can be held personally accountable for in the bankruptcy of PT.

Article 97 paragraphs (3) and paragraphs (4) regulate the responsibilities of directors for the company's losses arising from negligence in conducting its management duties, which can be classified as follows:

1. Members of the board of directors are fully responsible for the loss suffered by the company if:

a. Guilty,

b. Negligent in conducting his duties management of the company.

2. Members of the board of directors are jointly and severally liable for the company's losses. In the event the members of the board of directors consist of 2 (two) or more persons, Article 97 paragraph (4) enforces the principle of applying responsibilities jointly. The provisions of Article 97 paragraph (4) of the Company Law are:

"In the case of directors consisting of 2 (two) or more directors, the responsibilities referred to paragraph (3) shall apply jointly and severally to each member of the directors".

\section{Form of Negligence of Directors That Can Be Asked for Responsibility}

According to the Civil Code, a person's legal basis is declared negligent in conducting its obligations or achievements as stipulated in Article 1238 of the Civil Code (Civil Code), which reads: that is, if this engagement results in the debtor should be deemed to have been negligent with the allotted time [4].

From the formulation of Article 1238 of the Civil Code above it can be seen there are two conditions when a person is considered negligent or injured in a promise, namely:

1. In the time is specified in the agreement, but with the expiration of that time (due) the debtor has not conducted his obligations.

2. In the event of specific time is not determined, then the creditor has notified the debtor to conduct his obligations or achievements, but the creditor still does not conduct his obligations to the creditor.

"In the case of directors consisting of 2 (two) or more directors, the responsibilities referred to in paragraph (3) shall apply jointly and severally to each member of the directors".

Responsibility for the element of error especially negligence as contained

Article 1366 of the Civil Code. How exactly the management of directors' actions can be stated to be negligent resulted in the bankruptcy of the Company. As long as the directors conduct their duties and obligations with full responsibility, the members of the board of directors still have responsibilities limited responsibility which is the main characteristic of PT. Conversely, because being a member of the board of directors means occupying a position, the person occupying the position should assume responsibility if the duties and obligations are neglected or if the authority is abused. According to the explanation in Article 97 paragraph (2), what is meant by "full responsibility" is to pay attention to the Company "carefully" and "diligently". Starting from the explanation of this article, the obligation to conduct management with full responsibility is "obliged to be careful and careful in implementing management".

Negligence often known as negligence is behavior is not according to the standard of conduct (standard of conduct) stipulated in the law for the protection of community members against risks that are not clonal. "What is meant here is the act of inaccurate, less careful the heart that a seller or manufacturer should have a duty of care [1].

Carelessness questions the problem of negligence in taking the appropriate action to arise unintended consequences. In Indonesian civil law, carelessness enters mistakes in illegal acts. Associated with unlawful acts in the concept of Article 1365 of the Civil Code, then this negligence is one part of it, which is the part questions the carelessness or negligence. In other words, this negligence problem is also an act against the law.

An essential element in this negligence is the existence of a duty of care (obligation to care for the interests of others) is violated by the producer. This duty of care requires that directors should be careful in conducting their duties and obligations within the company.

Directors are considered negligent if there is no good faith by the directors, for example, to pay off debts to creditors. Directors are negligent in conducting debt payments to creditors. It is known the directors are not stated to be negligent or wrong which results in bankruptcy as long as the directors have a good intention with the reference of duty care and conduct management according to the authority given to him. However, if 
proven to the contrary result in bankruptcy, the board of directors can be held jointly liable through the bankruptcy proceedings at the Commercial Court

\section{CONCLUSION}

1. The Board of Directors is personally responsible for the bankruptcy of the company, if the bankruptcy is caused by an error of the board of directors in managing the company, and if the company's assets are insufficient to cover the debt, then the directors' wealth is also responsible for paying off the debt unless the directors can prove otherwise, where he has conducted his duties and responsibilities accordingly.

2. The Board of Directors is considered negligent if he does not conduct his duty carefully, based on the principle of prudence and good intentions, thus causing the company to go bankrupt

\section{ACKNOWLEDGMENT}

The author would like to the Dean of Faculty of Social Science, Manado State University in supporting the publication of this article.

\section{REFERENCES}

[1] Jono, Hukum Kepailitan. Jakarta: Sinar Grafika, 2008.

[2] M. Y. Harahap, Hukum perseroan terbatas. Jakarta: Sinar Grafika, 2009.

[3] H. M. Shuban, Hukum Kepailitan, Prinsip, Norma dan Praktik Peradilan. Jakarta: Kencana, 2008.

[4] M. Fuad, Perbuatan Melawan Hukum. Bandung: Citra Aditya Bakti, 2002. 